BADANIA I ROZWÓJ

mgr inż. Wiesław Leszkoa), dr inż. Krzysztof Gryza ${ }^{*}$

a) Centralny Instytut Ochrony Pracy - Państwowy Instytut Badawczy / Central Institute for Labour Protection - National Research Institute

*Autor korespondencyjny / Corresponding author: krgry@ciop.pl

\title{
Elektromagnetyczne zagrożenia balistyczne podczas służby funkcjonariuszy straży pożarnej
}

\author{
The Electromagnetic Ballistic Hazards Faced by Fire Service Officers While on Duty \\ Магнитные баллистические угрозы во время службы офицеров пожарной охраны
}

\begin{abstract}
ABSTRAKT
Cel: Pole magnetostatyczne (PMS) może być przyczyną przemieszczania się obiektów metalowych (ferromagnetycznych), które stanowi duże zagrożenie dla infrastruktury technicznej i ludzi znajdujących się w otoczeniu silnego źródła takiego pola. Takie zagrożenie wywołane przemieszczaniem się przedmiotów ferromagnetycznych w polu magnetostatycznym (PMS) potocznie określane jest jako zagrożenie balistyczne lub zagrożenie latającymi przedmiotami. Celem prezentowanych badań była analiza warunków możliwego wystąpienia elektromagnetycznych zagrożeń balistycznych podczas prowadzenia przez strażaków zróżnicowanych działań operacyjnych (ratowniczych, gaśniczych, rozpoznawczo-kontrolnych lub ewakuacji ćwiczebnych), a także określenie podatności indywidualnego wyposażenia strażaków oraz sprzętu ratowniczego na oddziaływanie PMS.

Projekt i metody: Podatność na PMS sprawdzono w badaniach zarówno indywidualnego wyposażenia strażaków, jak i sprzętu ratowniczego wykorzystywanego przez strażaków, stanowiącego wyposażenie pojazdu gaśniczego. Wyposażenie do badań wybrano na podstawie wizyt studyjnych w jednostkach ratowniczo-gaśniczych oraz wywiadów przeprowadzanych ze strażakami, analizy wymagań przepisów prawnych dotyczących funkcjonowania PSP, a także ogólnodostępnych materiałów szkoleniowych. Dla indywidualnego wyposażenia strażackiego oraz sprzętu ratowniczego, będącego na wyposażeniu wozu strażackiego, przeprowadzono doświadczalne badania podatności na oddziaływanie PMS wykonane z zastosowaniem magnesu ferrytowego charakteryzującego się minimalną wartością indukcji magnetycznej remanencji 0,37 T. Badania obejmowały obserwację położenia magnesu, zlokalizowanego swobodnie w odległości 5-10 cm od badanych elementów wyposażenia strażaka.

Wyniki: Stwierdzono, że wyposażenie strażackie, charakteryzuje się niewielką podatnością na oddziaływanie PMS. Odmienna sytuacja jest w przypadku elementów sprzętu ratowniczego. Zagrożenia balistyczne mogą mieć miejsce szczególnie w otoczeniu silnych źródeł PMS, takich jak medyczne skanery i laboratoryjne spektrometry rezonansu magnetycznego oraz chwytaki lub separatory magnetyczne, i powodować np. uszkodzenia sprzętu, uszkodzenie ciała, a nawet utratę życia. Funkcjonariusze straży pożarnej prowadzący działania operacyjne w bliskim otoczeniu skanerów i spektrometrów rezonansu magnetycznego mogą być narażeni na tego typu niebezpieczeństwa (najczęściej w placówkach medycznych i naukowych) z uwagi na specjalne procedury dezaktywacji magnesów i natychmiastowego przerwania generacji silnego PMS.

Wnioski: Rozporządzenie MSWiA dotyczące BHP w czasie pełnienia służby nie określa wymagań na wypadek prowadzenia działań ratowniczo-gaśniczych w narażeniu na silne PMS. Rozpoznanie, oznakowanie i eliminacja takich zagrożeń powinny być omawiane w ramach szkoleń i ćwiczeń dla strażaków. Słowa kluczowe: pole magnetostatyczne, zagrożenia balistyczne, pośrednie zagrożenia elektromagnetyczne Typ artykułu: oryginalny artykuł naukowy
\end{abstract}

Przyjęty: 12.09.2016; Zrecenzowany: 24.05.2017; Opublikowany: 30.06.2017;

Procentowy wkład merytoryczny: W. Leszko - 70\%, K. Gryz - 30\%;

Artykuł został wyróżniony przez Komitet Redakcyjny;

Proszę cytować: BiTP Vol. 46 Issue 2, 2017, pp. 12-27, doi: 10.12845/bitp.46.2.2017.1;

Artykuł udostępniany na licencji CC BY-NC-SA 4.0 (https://creativecommons.org/licenses/by-nc-sa/4.0/).

\section{ABSTRACT}

Aim: Static magnetic fields (SMF) can cause metal (ferromagnetic) objects to move and thus pose a serious hazard for the utilities and the people who are close to the source of strong SMF. These kinds of electromagnetic hazards are identified as "flying objects" or "ballistic hazards". The aim of this study was to analyse the conditions in which electromagnetic ballistic hazards can occur during the operations of Fire Service officers (rescue, firefighting, reconnaissance/inspection and evacuation drills) and also to test personal firefighter equipment and rescue equipment for SMF susceptibility. 
Project and methods: SMF susceptibility was tested for both personal firefighter equipment and fire-engine rescue equipment. The equipment to be tested was selected based on study visits to fire and rescue departments, and on the basis of interviews with firefighters, and also based on an analysis of the laws governing the functioning of the State Fire Service, as well as commonly available training materials. Both the personal firefighter equipment and fire-engine rescue equipment were subjected to experimental testing for SMF susceptibility. A ferrite permanent magnet with a minimum remanence of $0.37 \mathrm{~T}$ was used for the testing. Field testing involved the observation of the magnet's location, with the magnet located unconstrained within a distance of 5-10 cm from the tested firefighter equipment.

Results: We have found that personal firefighter equipment is only moderately susceptible to SMF, while pieces of rescue equipment show higher susceptibility. Furthermore, we have concluded that strong SMF sources, such as, especially, magnetic resonance imaging scanners and spectrometers, magnetic grippers and separators, might pose ballistic hazards in their surroundings, causing, for instance, damage to the equipment, bodily injuries, or even death. Firefighters engaging in operations near magnetic resonance imaging scanners or spectrometers are very likely to be exposed to these kinds of hazards (usually in medical centres and research institutes), since the immediate deactivation of the SMF of these devices is impracticable in emergencies, as it requires complex procedures to be followed. Conclusions: The Regulation of the Ministry of the Interior governing the safety of firefighters on duty does not specify any safety requirements for operations in the proximity of strong SMF sources. The identification, signage and elimination of hazards should be discussed during firefighters' training and exercises. Keywords: static magnetic field, ballistic hazards, indirect electromagnetic hazards Type of article: original scientific article

Received: 12.09.2016; Reviewed: 24.05.2017; Published: 30.06.2017;

Percentage contribution: W. Leszko - 70\%, K. Gryz - 30\%;

The article was recognised by the Editorial Committee

Please cite as: BiTP Vol. 46 Issue 2, 2017, pp. 12-27, doi: 10.12845/bitp.46.2.2017.1;

This is an open access article under the CC BY-NC-SA 4.0 license (https://creativecommons.org/licenses/by-nc-sa/4.0/).

\section{АННОТАЦИЯ}

Цель: Магнитостатическое поле (PMS) может вызвать перемешение металлических (ферромагнитных) объектов, представляюшее собой серьезную угрозу для технической инфраструктуры и людей, находяшихся поблизости мошного источника такого поля. Такую угрозу, вызванную перемешением ферромагнитных объектов в магнитном поле (PMS), как правило, называют баллистической угрозой или угрозой от летаюших предметов. Целью представленных исследований являлся анализ условий для возможного возникновения магнитных баллистических угроз во время проведения пожарными различных оперативных действий (спасательных, гасяших, разведки или эвакуационных тестов), а также определение чувствительности отдельных частей средств индивидуальной зашиты пожарных и спасательного оборудования к воздействию магнитостатического поля.

Проект и методы: Восприимчивость к PMS была проверена в испытаниях как индивидуального оснашения пожарных, так и спасательного оборудования пожарного автомобиля. Испытательное оборудование было выбрано на основе ознакомительных поездок в пожарно-спасательные подразделения и интервью с пожарными, анализа нормативных требований, касаюшихся функционирования PSP, а также обшедоступных учебных материалов. Для индивидуального оборудования и спасательного оборудования пожарного автомобиля были проведены экспериментальные испытания на воздействие PMS, в которых использовался ферритовый магнит, который характеризуется минимальным значением индукции остаточной намагниченности на уровне 0,37 Т. Исследования включали наблюдение положения магнита, свободно расположенного в пределах 5-10 см от исследуемых образцов оснашения пожарного.

Результаты: Было установлено, что противопожарное оборудование характеризуется низкой чувствительностью к воздействию РМS. Иначе обстоит дело в случае элементов спасательного оборудования. Баллистические угрозы могут возникнуть особенно около сильных источников PMS, таких как медицинские сканеры и лабораторные магнитно-резонансные спектрометры, а также захваты/грейферы или магнитные сепараторы. Такие угрозы могут приводить к повреждениям оборудования, травмам или даже гибели людей. Офицеры пожарной службы, осушествляюшие оперативную деятельность в непосредственной близости от сканеров и магнитно-резонансных спектрометров, могут быть подвержены такой опасности (чаше всего в медицинских и научных учреждениях) в связи с конкретными процедурами дезактивации магнитов и немедленного прекрашения сильного излучения PMS.

Выводы: Распоряжение Министерства внутренних дел и администрации относительно охраны здоровья и безопасности труда при исполнении служебных обязанностей не включает требований в случае проведения спасательно-гасяших работ при воздействии сильного РМS. Диагностика, определение и устранение таких угроз следует обсуждать во время обучения и тренировки пожарных.

Ключевые слова: магнитостатическое поле, баллистические угрозы, косвенные магнитные угрозы

Вид статьи: оригинальная научная статья

Принята: 12.09.2016; Рецензирована: 24.05.2017; Опубликована: 30.06.2017;

Процентное соотношение участия в подготовке статьи: W. Leszko - 70\%, K. Gryz - 30\%;

Эту статью наградил Редакционный Совет;

Просим ссылаться на статью следуюшим образом: BiTP Vol. 46 Issue 2, 2017, pp. 12-27, doi: 10.12845/bitp.46.2.2017.1;

Настояшая статья находится в открытом доступе и распространяется в соответствии с лицензией CC BY-NC-SA 4.0

(https://creativecommons.org/licenses/by-nc-sa/4.0/). 


\section{Wprowadzenie}

Silne pole magnetostatyczne (PMS) może stanowić źródło poważnych zagrożeń dla zdrowia i życia ludzi, a także poważnych uszkodzeń sprzętu i urządzeń znajdujących się w obszarze jego oddziaływania [1]. PMS o indukcji magnetycznej przekraczającej $3 \mathrm{mT}$ może spowodować wystąpienie tzw. zjawiska balistycznego, określanego również jako zagrożenie latającymi obiektami $[2,3]$. Polega ono na wprawieniu w ruch i przyciągnięciu do źródła obiektów ferromagnetycznych, czyli posiadających trwałe właściwości magnetyczne [4]. W silnym PMS w ruch mogą być wprawione obiekty o masie nawet wielu kilogramów, na które w polu o niejednorodnym rozkładzie przestrzennym oddziaływają siły przesunięcia i obrotu, znacznie przewyższające opory tarcia, a nawet przyciąganie ziemskie. Wraz z przesuwaniem się do źródła podlegają one oddziaływaniu coraz silniejszego PMS, które przyczynia się do gwałtownego wzrostu prędkości ich przemieszczania i energii kinetycznej. $Z$ tego powodu stanowią one duże zagrożenie dla infrastruktury technicznej i ludzi znajdujących się przy źródle [2]. Niestety incydenty, do których doszło z udziałem ww. latających obiektów, zazwyczaj nie są rejestrowane, o ile nie doprowadziły do strat w mieniu lub uszczerbków na zdrowiu. Utrudnia to ocenę rzeczywistej skali występowania problemu [2]. $Z$ doniesień prasowych znane są nawet przypadki ofiar śmiertelnych np. w wyniku uderzenia przez taki latający przedmiot przyciągnięty do magnesu skanera rezonansu magnetycznego [5].

\section{Cel}

Celem prezentowanych badań była analiza warunków możliwego wystąpienia elektromagnetycznych zagrożeń balistycznych podczas prowadzenia przez strażaków zróżnicowanych działań operacyjnych (ratowniczych, gaśniczych, rozpoznawczo-kontrolnych lub ewakuacji ćwiczebnych), a także określenie podatności indywidualnego wyposażenia strażaków oraz sprzętu ratowniczego na oddziaływanie PMS.

\section{Materiały i metody}

\section{Sprzęt objęty badaniami}

Z racji różnorodności środowisk, w których mogą być prowadzone działania operacyjne straży pożarnych (np. placówki medyczne, laboratoryjne, zakłady przemysłowe), zróżnicowane mogą być również występujące w nich źródła silnych PMS. W związku z powyższym badaniom podatności na PMS poddano zarówno indywidualne wyposażenie strażaków, jak i strażacki sprzęt ratowniczy, stanowiący wyposażenie pojazdu gaśniczego. Wyposażenie do badań wybrano na podstawie wizyt studyjnych w jednostkach ratowniczo-gaśniczych oraz wywiadów przeprowadzanych ze strażakami, analizy wymagań przepisów prawnych dotyczących funkcjonowania PSP, a także ogólnodostępnych materiałów szkoleniowych [6].

W skład indywidualnego wyposażenia strażaków, które zostało objęte badaniami wchodzą następujące grupy ekwipunku:

- odzież specjalna np. ubranie koszarowe,

- środki ochrony indywidualnej np. ubranie specjalne, hełm strażacki,

- ekwipunek osobisty np. pas strażacki z zatrzaśnikiem [7].

\section{Introduction}

Strong static magnetic field (SMF) can be a source of serious hazards to human health and life. It can also cause heavy damage to the equipment and devices located within its range [1]. SMF with a magnetic flux density of more than $3 \mathrm{mT}$ can induce the occurrence of the so-called ballistic event, also known as the flying object hazard [2, 3]. It involves the setting in motion, and attracting to SMF sources, of ferromagnetic objects, that is, objects with permanent magnetic properties [4]. A strong SMF can set in motion objects weighing as much as several kilogrammes. In a field without a uniform spatial distribution, these objects are exposed to displacement and rotation forces which substantially exceed the frictional resistances and even gravitation. As they move closer to the source, they become exposed to increasingly stronger SMF, which in turn cause their velocity and kinetic energy to rise abruptly. Consequently, they pose a major hazard for the utilities and for the people who are close to the source [2]. Regrettably, incidents involving flying objects are usually not reported, unless they have caused property damage or bodily injuries. This makes it difficult to determine the actual scale of the problem [2]. There have, however, been press reports of fatalities - for instance, as a result of being hit by a flying object attracted to the magnet of a magnetic resonance imaging scanner [5].

\section{Aim}

The aim of this study was to investigate the conditions in which there is a potential of electromagnetic ballistic hazards during a number of firefighting operations (reconnaissance, rescue, extinguishing and fire drills), and also to determine the susceptibility of personal firefighter equipment and rescue equipment to SMF.

\section{Materials and methods}

\section{The equipment tested}

Firefighting operations can be conducted in a great variety of environments (medical centres, laboratories, industrial facilities), which, by extension, contain varied sources of strong SMF. Cognisant of this fact, we tested both personal firefighter equipment and fire-engine rescue equipment for SMF susceptibility. The equipment to be tested was selected based on study visits to fire and rescue departments, and on the basis of interviews with firefighters. This selection was also built upon an analysis of the laws governing the functioning of the State Fire Service, and on commonly available training materials [6].

The personal firefighter equipment tested comprised the following gear groups:

- special clothing, such as station wear;

- personal protective measures, specialised clothing, fire helmets;

- personal gear, the firefighter's belt with a snap hook [7]. 
Dodatkowo strażacy mogą być wyposażeni w latarkę ręczną lub nahełmową, nóż ratowniczy lub podręczne narzędzie wielofunkcyjne tzw. multitool oraz radiotelefon nasobny.

W trakcie działań operacyjnych strażacy korzystają ze sprzętu do ratowania i zabezpieczania osób, zwierząt, środowiska i mienia, których życie lub stan techniczny jest zagrożony z powodu pożaru, katastrofy lub innego nagłego, losowego, nieprzewidzianego zdarzenia.

Badaniami objęto następujące grupy zasadniczego sprzętu ratowniczego:

- hydrauliczne narzędzia ratownicze (rozpieracze, nożyce) - średnia masa urządzeń zawiera się w przedziale od 10 do $30 \mathrm{~kg}$. Narzędzia te służą do torowania dróg dojścia oraz ratowania ludzi, zwierząt i mienia, do których dojście jest utrudnione na skutek katastrof drogowych, kolejowych lub budowlanych, spowodowanych siłami natury lub przez człowieka,

- mechaniczny sprzęt tnący (piły tarczowe i łańcuchowe) - średnia masa urządzeń zawiera się w przedziale od 8 do $15 \mathrm{~kg}$. Sprzęt ten wykorzystywany jest w akcjach ratowniczych polegających na usuwaniu przeszkód w formie konstrukcji metalowych, drewnianych i betonowych, pojazdów mechanicznych i innych przedmiotów utrudniających bezpieczną i skuteczną pracę ratownika,

- sprzęt burzący (łomy, topory, podnośniki, wyciągarki) średnia masa urządzeń zawiera się $\mathrm{w}$ przedziale od 5 do $12 \mathrm{~kg}$. Sprzęt burzący wyróżnia się prostą konstrukcją oraz tym, że użytkuje się go przy użyciu siły ludzkich rąk, systemów dźwigni lub bloczków [6].

Badaniami objęto również aparaty ochrony dróg oddechowych, w które wyposażeni są strażacy w trakcie prowadzenia działań gaśniczych. W skład aparatu wchodzi maska twarzowa z podłączanym automatem oddechowym, reduktor, manometr oraz noszak, do którego przyczepiana jest butla.

\section{Procedura badań podatności sprzętu indywidualnego oraz} ratowniczego na oddziaływanie PMS

Doświadczalne badania podatności elementów wyposażenia strażackiego i sprzętu ratowniczego na oddziaływanie PMS wykonano z zastosowaniem walcowego magnesu ferrytowego o średnicy $58 \mathrm{~mm}$ i wysokości $18 \mathrm{~mm}$. Magnes ten został wykonany z materiału magnetycznego o oznaczeniu F30, charakteryzującego się minimalną wartością indukcji magnetycznej remanencji 0,37 T.

Badania terenowe polegały na obserwacji położenia magnesu, zlokalizowanego swobodnie w odległości $5-10 \mathrm{~cm}$ od badanych elementów wyposażenia strażaka. Jeżeli magnes był wprawiony w ruch w wyniku oddziaływania między PMS magnesu i elementem ekwipunku lub sprzętu, to uznawano go za element o cechach ferromagnetycznych, dokonując następnie identyfikacji, jakie jego części były szczególnie podatne na oddziaływania PMS. Element nie przyciągający magnesu, kwalifikowany był jako nie posiadający cech ferromagnetycznych i nie zajmowano się jego dalszymi badaniami.
Firefighters may be additionally equipped with a hand torch or a helmet-mounted flashlight, a rescue knife, a multi-tool and a portable radiotelephone.

During their operations, firefighters use equipment designed to rescue and protect people, animals, environments and property in which lives or technical condition are at risk due to fire, disaster or sudden, random and unforeseeable events.

The study included the following groups of primary rescue equipment:

- hydraulic rescue tools (spreaders, shears) - the average weight of these tools ranges from 10 to $30 \mathrm{~kg}$. These tools are used to clear access and save people, animals and property, the access to whom or which is blocked as a result of road traffic, rail and construction disasters brought about by natural phenomena or human activity.

- mechanical cutting equipment (circular saws and chainsaws) - the average weight of these ranges from 8 to $15 \mathrm{~kg}$. This equipment is used in rescue operations involving the removal of such obstacles as steel, wooden and concrete structures, motor vehicles and other objects compromising the safety and effectiveness of rescue work;

- demolition equipment (crowbars, axes, jacks, hoists) - the average weight of these ranges from 5 to $12 \mathrm{~kg}$. Demolition equipment has a distinctly simple design and is operated using manual force, lever systems and pulleys [6].

The study also included the breathing apparatus used by firefighters during extinguishing operations. An apparatus set includes a face mask with an inhalator, a pressure reducer, a pressure gauge and a backpack to which the air tank is attached.

\section{Personal and rescue equipment SMF susceptibility testing} procedures

The experimental testing of the individual pieces of firefighting and rescue equipment for their SMF susceptibility was conducted using a cylindrical permanent ferrite magnet with a diameter of $58 \mathrm{~mm}$ and a height of $18 \mathrm{~mm}$. This magnet was made of $\mathrm{F} 30$ magnetic material which had a minimum remanence of $0.37 \mathrm{~T}$.

Field testing involved the observation of the magnet's location, with the magnet located unconstrained within a distance of 5-10 cm from the tested firefighter equipment. If a piece of personal or rescue equipment was set in motion by the magnet's SMF, we classified such piece of equipment as ferromagnetic, and then we identified which parts of it were particularly susceptible to SMF. Equipment which the magnet did not attract was classified as not being ferromagnetic and excluded from further testing. 


\section{Rozpoznanie źródeł PMS}

Na podstawie analizy danych zebranych przez CIOP-PIB dokonano rozpoznania charakterystyki źródeł silnych PMS, z którymi strażacy mogą mieć do czynienia w przypadku działań operacyjnych prowadzonych np. w ośrodkach diagnostyki medycznej lub weterynaryjnej, laboratoriach biologicznych i chemicznych, magazynach lub zakładach produkcji wyrobów metalowych i mogących stworzyć potencjalne zagrożenie wypadkowe z uwagi na wystąpienie zjawiska balistycznego. Przykładowe scenariusze zdarzeń wypadkowych omówiono na podstawie statystyk dotyczących rodzajów oraz ilości interwencji strażackich zamieszczonych $\mathrm{w}$ biuletynie publicznym PSP [8].

\section{Wyniki badań}

\section{Podatność wyposażenia strażackiego i sprzętu ratowniczego} na oddziaływanie PMS

Spośród wymienionych grup ekwipunku, odzież ochronna oraz środki ochrony indywidualnej, takie jak ubiór koszarowy i ubranie specjalne są wykonane z materiałów tekstylnych (np. bawełna, poliester, tkaniny kevlarowe, nomexowe), a także z włókien szklanych oraz skóry, i nie wykazują one właściwości ferromagnetycznych. Natomiast występowanie materiałów o takich właściwościach zostało stwierdzone w przypadku niektórych elementów wyposażenia indywidualnego (tabela 1).

\section{SMF source identification}

First, an analysis was conducted of the data collected by the Central Institute for Labour Protection - National Research Institute (CIOP-PIB). Based on the findings this analysis provided, we identified the characteristics of the strong SMF sources which firefighters might deal with during operations in medical diagnostics centres or veterinary diagnostics centres, biological and chemical laboratories, warehouses, as well as steel-product manufacturing facilities, and which can pose a potential accident hazard due to a ballistic event. Examples of accident scenarios are discussed on the basis of statistics concerning the types and number of fire-service interventions, as published in the official journal of the Polish State Fire Service [8].

\section{Results}

Personal and rescue equipment SMF susceptibility

The above-mentioned equipment groups include equipment which exhibits no ferromagnetic properties. This includes personal protective clothing and measures, such as station wear and specialised clothing which is made of textiles (e.g. cotton, polyester, Kevlar and Nomex fibres), glass fibres and leather. Materials with ferromagnetic properties were found as well in some pieces of personal firefighter equipment (Table 1).

Tabela 1. Podatność na oddziaływanie pola magnetostatycznego - wyniki badań doświadczalnych dotyczących elementów wyposażenia indywidualnego strażaka

Table 1. Susceptibility to static magnetic field - results of experimental testing on personal firefighter equipment.

\begin{tabular}{|c|c|c|c|c|}
\hline $\begin{array}{l}\text { Lp. I } \\
\text { No. }\end{array}$ & $\begin{array}{l}\text { Elementy wyposażenia indywidualnego / } \\
\text { Piece of personal equipment }\end{array}$ & $\begin{array}{c}\text { Przybliżona masa / } \\
\text { Approximate weight } \\
\text { [kg] }\end{array}$ & $\begin{array}{c}\text { Materiały, z których wykonano element / } \\
\text { Materials the piece of equipment } \\
\text { is made of }\end{array}$ & $\begin{array}{c}\text { Zidentyfikowana część elementu } \\
\text { o właściwościach ferromagnetycznych / } \\
\text { The identified ferromagnetic parts } \\
\text { of the piece }\end{array}$ \\
\hline 1. & pas strażacki / firefighter's belt & 0,9 & $\begin{array}{l}\text { poliamid, skóra, metal / } \\
\text { polyamide, leather, metal }\end{array}$ & klamra, uchwyt / buckle, handle \\
\hline 2. & toporek strażacki / fire axe & 2,5 & stal hartowana / hardened steel & cały toporek / entire tool \\
\hline 3. & latarka ręczna / hand-held torch & 0,15 & $\begin{array}{c}\text { Obudowa - propolimer, poliwęglan } \\
\text { Akumulator - metal, np. kadm, nikiel } \\
\text { lub mangan / Casing - pro-polymer, } \\
\text { polycarbonate } \\
\text { Battery - metal, e.g. cadmium, nickel } \\
\text { or manganese }\end{array}$ & ogniwa w akumulatorze /battery cells \\
\hline 4. & latarka hełmowa / helmet flashlight & 0,20 & $\begin{array}{c}\text { Obudowa - propolimer } \\
\text { Akumulator - metal, np. kadm, nikiel lub } \\
\text { mangan/ casing - } \\
\text { pro-polymer, battery - metal, e.g. } \\
\text { cadmium, nickel or manganese }\end{array}$ & $\begin{array}{l}\text { ogniwa w akumulatorze / } \\
\text { battery cells }\end{array}$ \\
\hline 5. & $\begin{array}{l}\text { podręczne narzędzie wielofunkcyjne } \\
\text { multitool / multi-tool }\end{array}$ & 0,20 & stal nierdzewna / stainless steel & całe narzędzie / entire tool \\
\hline 6. & $\begin{array}{l}\text { radiotelefon ręczny / } \\
\text { handheld radiotelephone }\end{array}$ & 0,6 & $\begin{array}{l}\text { plastikowa obudowa dookoła płytki } \\
\text { z elementami elektronicznymi / } \\
\text { plastic casing around the plate's } \\
\text { electronic components }\end{array}$ & $\begin{array}{l}\text { elementy wbudowanego głośnika, } \\
\text { akumulatory / elements of the } \\
\text { built-in loudspeaker, batteries }\end{array}$ \\
\hline 7. & $\begin{array}{l}\text { zatrzaśnik/karabińczyk / } \\
\text { snap hook/snaplink }\end{array}$ & 0,20 & duraluminium / duralumin & $\begin{array}{l}\text { element nieferromagnetyczny / } \\
\text { non-ferromagnetic object }\end{array}$ \\
\hline
\end{tabular}

Źródło: Opracowanie własne.

Source: Own elaboration. 
W tabeli 2 zaprezentowano wyniki badań sprzętu ratowniczego ze względu na jego właściwości ferromagnetyczne.
Table 2 presents the results of rescue equipment testing for ferromagnetic properties.

Tabela 2. Podatność na oddziaływanie pola magnetostatycznego - wyniki badań doświadczalnych dotyczących sprzętu ratowniczego użytkowanego przez jednostki straży pożarnych

Table 2. Susceptibility to static magnetic field - the results of experimental testing on personal firefighter equipment

\begin{tabular}{|c|c|c|c|c|}
\hline $\begin{array}{l}\text { Lp. / } \\
\text { No. }\end{array}$ & $\begin{array}{l}\text { Strażacki sprzęt ratowniczy / } \\
\text { Firefighting rescue equipment }\end{array}$ & $\begin{array}{l}\text { Przybliżona masa / } \\
\text { Approximate weight } \\
\text { [kg] }\end{array}$ & $\begin{array}{c}\text { Materiały, z których wykonano element / } \\
\text { Materials the piece of equipment } \\
\text { is made of }\end{array}$ & $\begin{array}{c}\text { Zidentyfikowana część elementu } \\
\text { o właściwościach ferromagnetycznych / } \\
\text { The identified ferromagnetic parts } \\
\text { of the piece }\end{array}$ \\
\hline 1. & $\begin{array}{l}\text { rozpieracze hydrauliczne / } \\
\text { hydraulic spreader }\end{array}$ & $10-28$ & stal / steel & wymienne ostrza / replaceable blades \\
\hline 2. & $\begin{array}{l}\text { rozpieracze kolumnowe / } \\
\text { column spreader }\end{array}$ & $10-21$ & stal / steel & cylinder, tłoczyska / cylinder, piston rods \\
\hline 3. & $\begin{array}{l}\text { nożyce hydrauliczne / } \\
\text { hydraulic shears }\end{array}$ & $9-15$ & stal / steel & wymienne ostrza / replaceable blades \\
\hline 4. & $\begin{array}{l}\text { nożyco-rozpieracze „combi" / } \\
\text { hydraulic combination tools }\end{array}$ & $9-20$ & stal / steel & wymienne ostrza / replaceable blades \\
\hline 5. & $\begin{array}{l}\text { pilarki łańcuchowe do drewna / } \\
\text { chainsaw for wood }\end{array}$ & 8 & metal / metal & prowadnica, łańcuch / track, chain \\
\hline 6. & $\begin{array}{l}\text { piły tarczowe do stali i betonu / } \\
\text { circular saw }\end{array}$ & $12-15$ & metal / metal & $\begin{array}{l}\text { tarcza, osłony tarczy, cylindrów } \\
\text { silnikowych, świec, tłumik wydechu / } \\
\text { disc, disc cover, engine cylinders, } \\
\text { spark plugs, mufflers }\end{array}$ \\
\hline 7. & $\begin{array}{l}\text { platforma hydrauliczna przesuwu } \\
\text { bocznego / plumbing platform } \\
\text { for side moving }\end{array}$ & $20-25$ & metal / metal & cała platforma / the whole platform \\
\hline 8. & $\begin{array}{l}\text { przewody hydrauliczne / } \\
\text { hydraulic hose }\end{array}$ & 1 & poliuretan, metal / polyurethane, metal & metalowe złączki/ metal adapters \\
\hline 9. & $\begin{array}{l}\text { osprzęt pneumatyczny wraz z przewodami / } \\
\text { pneumatic tools along with hoses }\end{array}$ & 1 & poliuretan, metal / polyurethane, metal & $\begin{array}{c}\text { metalowe złączki na końcach przewodów, } \\
\text { reduktor ciśnienia / metal adapters on } \\
\text { hose ends, pressure reducer }\end{array}$ \\
\hline 10. & $\begin{array}{l}\text { agregat hydrauliczny / } \\
\text { hydraulic power generator }\end{array}$ & $10-40$ & metal / metal & cały agregat / the whole generator \\
\hline 11. & $\begin{array}{l}\text { zestaw podpór stabilizacyjnych / } \\
\text { set of stabilising supports }\end{array}$ & $5-10$ & metal / metal & cały zestaw / whole set \\
\hline 12. & hooligan / hooligan & 9 & stal hartowana / hardened steel & całe urządzenie / whole tool \\
\hline 13. & siekiera / axe & 2,5 & drewno, metal / wood, metal & $\begin{array}{l}\text { cała powierzchnia ostrza / } \\
\text { the entire blade }\end{array}$ \\
\hline 14. & szpadel / spade & $1,5-2$ & drewno, metal / wood, metal & łyżka/czerpak / scoop-head \\
\hline 15. & $\begin{array}{l}\text { młot, narzędzia burzące / } \\
\text { hammer, demolishing tools }\end{array}$ & 5 & drewno, metal / wood, metal & obuch / head \\
\hline 16. & $\begin{array}{l}\text { podręczny sprzęt gaśniczy (gaśnice) / } \\
\text { portable fire extinguishers }\end{array}$ & 6 & stal / steel & $\begin{array}{l}\text { cała zewnętrzna obudowa zbiornika, } \\
\text { zawór wylotowy / the entire outer casing } \\
\text { of the tank, the exhaust valve }\end{array}$ \\
\hline 17. & $\begin{array}{l}\text { zestaw transportowy, wózki } \\
\text { do przemieszczania / transport set, } \\
\text { carts for carrying tools }\end{array}$ & $3-4$ & metal / metal & cały zestaw / whole set \\
\hline 18. & szekle / shackles & $0,5-4$ & metal, żeliwo / metal, cast iron & cały zestaw / whole set \\
\hline 19. & wspornik progowy / bracket & $1,5-2$ & stal węglowa / carbon steel & cały wspornik / whole bracket \\
\hline 20. & $\begin{array}{l}\text { talerze ślizgowe (podkłady pod podpory) / } \\
\text { slide plates (support bases) }\end{array}$ & $2-4$ & metal, żeliwo / metal, cast iron & cały talerz / the entire plate \\
\hline 21. & $\begin{array}{l}\text { wyciągarka ręczna / } \\
\text { hand-operated hoist }\end{array}$ & $15-18$ & metal / metal & całe urządzenie / whole tool \\
\hline 22. & $\begin{array}{l}\text { pompa ręczna hydrauliczna / } \\
\text { hand-operated hydraulic pump }\end{array}$ & $5-12$ & metal / metal & całe urządzenie / whole tool \\
\hline 23. & przecinak do pedałów / pedal cutter & 2 & stal / steel & całe urządzenie / whole tool \\
\hline 24. & $\begin{array}{l}\text { młoty udarowe z zakończeniami oraz } \\
\text { inne wiertarki / drill hammers with end } \\
\text { pieces and other drills }\end{array}$ & $5-30$ & stal / steel & $\begin{array}{l}\text { cała obudowa oraz wymienne } \\
\text { zakończenia / whole casing and } \\
\text { replaceable end pieces }\end{array}$ \\
\hline 25. & butla z powietrzem / air tank & $3-7$ & $\begin{array}{l}\text { stalowa lub kompozytowa / } \\
\text { steel or composite }\end{array}$ & cała obudowa / whole casing \\
\hline 26. & klucze hydrantowe / hydrant wrenches & $0,3-1$ & stal / steel & cały klucz / whole wrench \\
\hline
\end{tabular}




\begin{tabular}{|c|c|c|c|c|}
\hline $\begin{array}{l}\text { Lp. I } \\
\text { No. }\end{array}$ & $\begin{array}{l}\text { Strażacki sprzęt ratowniczy / } \\
\text { Firefighting rescue equipment }\end{array}$ & $\begin{array}{l}\text { Przybliżona masa / } \\
\text { Approximate weight } \\
{[\text { [kg] }}\end{array}$ & $\begin{array}{c}\text { Materiały, z których wykonano element / } \\
\text { Materials the piece of equipment } \\
\text { is made of }\end{array}$ & $\begin{array}{c}\text { Zidentyfikowana część elementu } \\
\text { o właściwościach ferromagnetycznych / } \\
\text { The identified ferromagnetic parts } \\
\text { of the piece }\end{array}$ \\
\hline 27. & $\begin{array}{l}\text { przecinak do samochodowych pasów } \\
\text { bezpieczeństwa / seat belt cutter }\end{array}$ & 0,1 & plastik, ostrze stalowe / plastic steel blade & ostrze / blade \\
\hline 28. & prądownica pianowa / foam nozzle & 2 & stal kwasoodporna / acid-resistant steel & $\begin{array}{c}\text { element nieferromagnetyczny / } \\
\text { non-ferromagnetic object }\end{array}$ \\
\hline 29. & $\begin{array}{l}\text { działko wodno-pianowe } 2 \times 75 \text { / } \\
\text { water-foam monitor } 2 \times 75\end{array}$ & 2 & aluminium, mosiądz / aluminium, brass & $\begin{array}{c}\text { element nieferromagnetyczny / } \\
\text { non-ferromagnetic object }\end{array}$ \\
\hline 30. & $\begin{array}{l}\text { działko wodno-pianowe } 3 \times 75 \text { / } \\
\text { water-foam monitor } 2 \times 75\end{array}$ & 3 & aluminium, mosiądz / aluminium, brass & $\begin{array}{l}\text { element nieferromagnetyczny / } \\
\text { non-ferromagnetic object }\end{array}$ \\
\hline
\end{tabular}

Źródło: Opracowanie własne.

Source: Own elaboration.

$\mathrm{Na}$ podstawie przeprowadzonych badań stwierdzono, że większość sprzętu ratowniczego eksploatowanego przez jednostki straży pożarnej jest wykonana z materiałów szczególnie podatnych na oddziaływanie PMS. Z tego względu może zostać on przyciągnięty do źródła PMS. Tylko nieliczne elementy wyposażenia nie wykazują wrażliwości na oddziaływanie PMS.

\section{Charakterystyka źródeł silnych PMS}

PMS jest rodzajem pola magnetycznego niezmiennego w czasie (o częstotliwości $0 \mathrm{~Hz}$ ), którego źródłami w środowisku pracy są m.in. elektromagnesy zasilane prądem stałym, magnesy trwałe lub instalacje stałoprądowe [9]. Najsilniejsze PMS emitują elektromagnesy skanerów i spektrometrów rezonansu magnetycznego, eksploatowane w placówkach medycznych, naukowych lub laboratoriach analitycznych.

W tym przypadku źródłem jednorodnego PMS, które występuje nieprzerwanie 24 godziny na dobę, jest elektromagnes nadprzewodzący o indukcji magnetycznej najczęściej od 0,5 do $3 \mathrm{~T}$ (w przypadku skanera), a nawet do $20 \mathrm{~T}$ (w przypadku spektrometru) [3]. Dla porównania, indukcja magnetyczna pola geomagnetycznego na obszarze Polski wynosi ok. 0,00004 T [1].

Proces aktywacji elektromagnesu nadprzewodzącego jest złożony i kosztowny - wymaga m.in. obniżenia temperatury uzwojenia elektromagnesu do ok. $4 \mathrm{~K}$ (tj. ok. $\left.-270^{\circ} \mathrm{C}\right)$ i utrzymania go w takich warunkach, aby uzyskać w nim zjawisko nadprzewodnictwa. W tym celu niezbędna jest specjalna instalacja chłodząca z ciekłym helem. W urządzeniach z elektromagnesami nadprzewodzącymi nie stosuje się rutynowego wyłączania PMS po zakończeniu pracy z urządzeniem, jak w przypadku innych źródeł PMS. Ponadto charakterystyczną cechą elektromagnesu nadprzewodzącego jest działanie aktywowanego elektromagnesu niezależne od zasilania elektrycznego (taki elektromagnes po uruchomieniu jest urządzeniem autonomicznym, dopóki temperatura uzwojenia jest utrzymywana na odpowiednio niskim poziomie). W sytuacjach awaryjnych można spowodować natychmiastowe dezaktywowanie elektromagnesu nadprzewodzącego jedynie poprzez zastosowanie specjalnej procedury i wyposażenia awaryjnego.

Nieliczne skanery rezonansu magnetycznego mają magnesy trwałe o indukcji magnetycznej poniżej 0,5 T. Z kolei ich rozmagnesowanie jest możliwe jednorazowo (trwale) po poddaniu magnesów obróbce termicznej w temperaturze przekraczającej wartość charakterystyczną dla materiału, z którego wykonany jest konkretny magnes, zwaną punktem Curie (np. ok. $1114^{\circ} \mathrm{C}$ dla kobaltu, $770^{\circ} \mathrm{C}$ dla żelaza i $354^{\circ} \mathrm{C}$ dla niklu).
The study led to the conclusion that most pieces of rescue equipment operated by fire service departments were made of materials particularly susceptible to SMF. Consequently, this equipment can be attracted to the SMF source. Only a few pieces of the equipment were found to be non-susceptible to SMF.

\section{Characteristics of strong SMF sources}

SMF is a type of time-invariant magnetic field (with a frequency of $0 \mathrm{~Hz}$ ) whose sources in the working environment include DC electromagnets, permanent magnets or DC installations [9]. The strongest SMF is emitted by electromagnets of magnetic resonance imaging scanners and spectrometers utilised in medical centres, research institutions or analytical laboratories.

In this case, the source of a 24-hour-a-day uniform SMF is the superconducting electromagnet with a magnetic flux density usually ranging from 0.5 to $3 \mathrm{~T}$ (for scanners) up to $20 \mathrm{~T}$ (for spectrometers) [3]. For comparison, the magnetic flux density of the geomagnetic field within Poland is about $0.00004 \mathrm{~T}$ [1].

Activating a superconducting electromagnet is a complex and costly process - it requires, among other conditions, the temperature of the electromagnet's winding to be reduced to about $4 \mathrm{~K}$ (i.e. about $-270^{\circ} \mathrm{C}$ ), and the electromagnet must be kept in this temperature to generate super conduction. To achieve this, a special liquid helium cooling system must be used. In devices with superconducting electromagnets, SMF is not routinely switched off after the operator finishes operating the device, as is the case with other SMF sources. Another distinctive feature of superconducting electromagnets is that once activated, they remain active even without power supply (after activation, such an electromagnet is an independent device as long as the winding's temperature is kept sufficiently low). In emergency situations, superconducting electromagnets can be deactivated immediately. This can be only done, however, by means of a special procedure and emergency equipment.

A few magnetic resonance imaging scanners have permanent magnets with a magnetic flux density of less than $0.5 \mathrm{~T}$. They can be demagnetised only once (permanently), when subjected to temperatures in excess of the characteristic values for the respective materials they are made of, called the Curie point (e.g. about $1,114^{\circ} \mathrm{C}$ for cobalt, $770^{\circ} \mathrm{C}$ for iron and $354^{\circ} \mathrm{C}$ for nickel). 
PMS występuje nieprzerwanie (24 godziny na dobę) w otoczeniu magnesów nadprzewodzących i trwałych, dlatego urządzenia tego rodzaju stanowią najistotniejsze źródło zagrożeń.

Silne PMS występuje również przy chwytakach i separatorach magnetycznych, wykorzystywanych w przedsiębiorstwach przemysłowych - zazwyczaj wyposażonych w elektromagnes rdzeniowy, którego zasilanie może być wyłączone w dowolnym momencie.

\section{Skanery rezonansu magnetycznego}

Urządzenia te służą do obrazowych badań diagnostycznych ciała pacjenta (rycina 1). Aby uzyskać obraz diagnostyczny, pacjent umieszczany jest w PMS [3].

Większość tego typu urządzeń eksploatowana jest w szpitalach lub ambulatoryjnych placówkach diagnostyki medycznej jako urządzenia stacjonarne. Możliwa jest ich eksploatacja w naukowych placówkach weterynaryjnych i biologicznych. Skaner może być również zlokalizowany na naczepie ciągnika siodłowego i wyposażony $w$ indywidualny agregat elektryczny (akumulatorowy) podtrzymujący zasilanie instalacji chłodzącej magnes podczas transportu. Skanery mobilne stosowane są zazwyczaj jako rozwiązanie tymczasowe dla specjalistycznych placówek medycznych, podczas przeprowadzenia prac serwisowych urządzeń stacjonarnych lub jako rozwiązanie umożliwiające dotarcie do pacjentów z małych miejscowości.

Zazwyczaj skanery i miejsca ich eksploatacji nie są oznakowane wymaganymi przez przepisy bezpieczeństwa i higieny pracy znakami ostrzegawczymi, informującymi o źródłach PMS i występujących w ich otoczeniu zagrożeniach dla ludzi i infrastruktury technicznej (np. brak takich widocznych oznaczeń). Przykład braku oznakowania przedstawiono na rycinie 1.
SMF is constantly present ( 24 hours a day) around superconducting and permanent magnets, so these devices are the major source of hazard.

Strong SMF is also found around magnetic grippers and separators used in industrial facilities. Usually, these are equipped with core electromagnets whose supply can be switched off at any time.

\section{Magnetic resonance imaging scanners}

These devices are intended for the diagnostic imaging of patients' bodies (Figure 1). To obtain an image, the patient has to be placed within the SMF [3].

These devices are in use, as stationary devices, mainly in hospitals and outpatient clinics. However, they can also be utilised in veterinary and biological research institutions. What is more, these scanners can be placed on semitrailers of truck-tractors, as well as be equipped with power generating units (battery powered) which power the magnet-cooling systems during transport. Mobile scanners are usually used as a temporary solution for specialised medical centres while their stationary devices are undergoing maintenance. Alternatively, these can prove helpful when patients from small towns have to be reached for testing.

Scanners and the sites where they are utilised are usually not marked with the warning signs required under the OSH regulations to advise of SMF sources and the potential risks that exist around them for humans and utilities (e.g. no such signs can be seen in Figure 1).

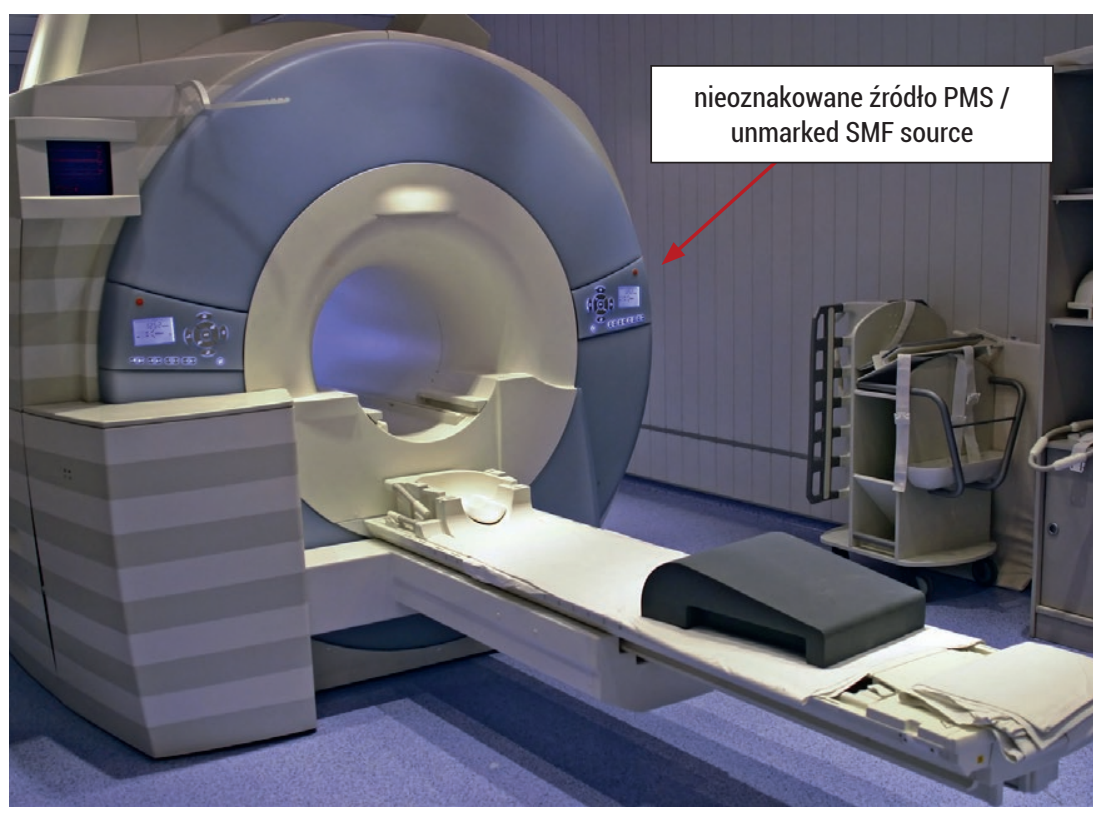

Rycina 1. Przykładowy stacjonarny skaner rezonansu magnetycznego do medycznych badań diagnostycznych

Figure 1. Example of a stationary magnetic resonance imaging scanner for medical diagnostic imaging

Źródło/Source: Fot. smart.art/Bigstockphoto. 
Skanery rezonansu magnetycznego mogą być mylone z tomografami komputerowym (CT), ze względu na podobieństwo i typowe użytkowanie obu rodzajów urządzeń w pracowniach diagnostycznych placówek medycznych [10].

\section{Spektrometry rezonansu magnetycznego}

Spektrometry rezonansu magnetycznego to urządzenia wykorzystywane w różnych przemysłowych laboratoriach analitycznych (np. chemicznych lub farmaceutycznych) lub naukowych laboratoriach analitycznych na uczelniach lub w instytutach badawczych. Urządzenia te pozwalają na badanie składu chemicznego analizowanej substancji umieszczonej w silnym PMS (rycina 2).
Magnetic resonance imaging scanners can be mistaken with computer-tomography scanners. Indeed, they are similar and are also usually used in the diagnostic departments of medical centres [10].

\section{Magnetic resonance imaging scanners}

Magnetic resonance spectrometers are used at various industrial laboratories (e.g. chemical or pharmaceutical) or university research laboratories and research institutes. These devices can be used to investigate the chemical composition of substances placed within a strong SMF (Figure 2).

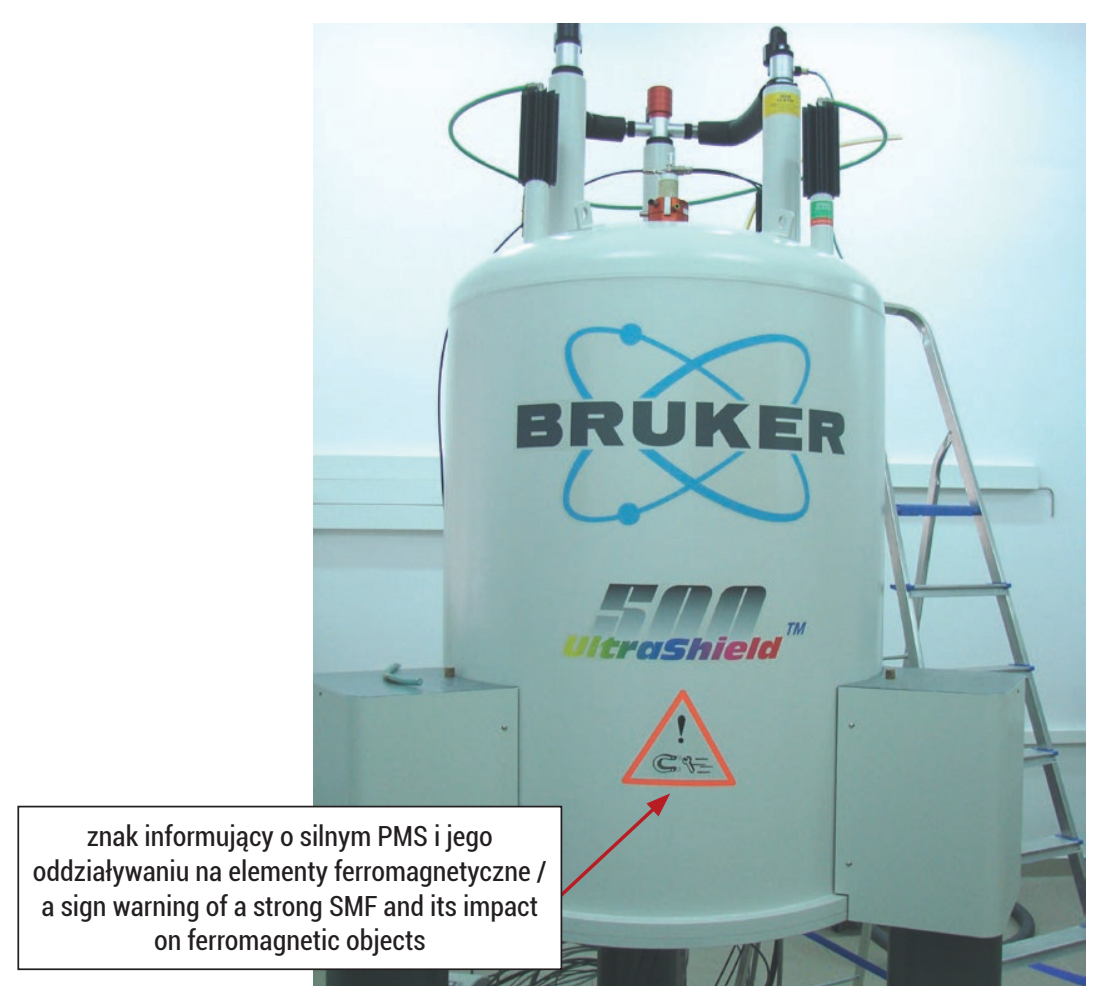

Rycina 2. Przykładowy spektrometr rezonansu magnetycznego do badania składu chemicznego substancji

Figure 2. Example of a magnetic resonance spectrometer used for chemical composition analysis

Źródło/Source: https://commons.wikimedia.org/wiki/File:Bruker_Avance_DPX_250_NMR_Spectrometer.jpg.

\section{Chwytaki magnetyczne}

Chwytaki magnetyczne to urządzenia służące do podnoszenia lub przenoszenia ciężkich elementów metalowych. Znajdują one zastosowanie $w$ wielu składach stali, fabrykach, magazynach, warsztatach, gdzie mogą być pomocne przy przenoszeniu blach, płyt i innych dużych stalowych elementów.

\section{Separatory magnetyczne}

Separatory magnetyczne to urządzenia służące do oddzielania zanieczyszczeń o właściwościach ferromagnetycznych z materiałów sypkich lub granulowatych. Znajdują one zastosowanie m.in. przy taśmociągach eksploatowanych w liniach recyklingu lub segregacji odpadów, a także $w$ przetwórstwie pasz i zbóż, przy wytwarzaniu płyt wiórowych oraz wykorzystaniu innych materiałów rozdrobnionych np. węgla lub biomasy w elektrowniach.

\section{Magnetic grippers}

Magnetic grippers are devices used to lift and handle heavy metal components. They are used in many steel storage facilities, plants, warehouses and workshops, where they can facilitate the handling of metal sheets and other large steel components.

\section{Magnetic separators}

Magnetic separators are used to separate ferromagnetic impurities from loose and granular materials. They are employed, for instance, for conveyor-belt flights in recycling or waste-segregation lines, as well as in fodder and grain processing, the manufacture of chipboards, or when other loose materials, such as coal or biomass, are used in power plants. 
Charakterystyka zagrożeń związanych z eksploatacją źródeł silnego PMS

W tabeli 3 przedstawiono charakterystykę omówionych wcześniej źródeł silnego PMS dotyczącą warunków wystąpienia zagrożeń balistycznych w PMS o indukcji magnetycznej przekraczającej $3 \mathrm{mT}$, z uwzględnieniem możliwości lub braku możliwości wyłączenia generacji PMS.

\section{Specification of hazards related to strong SMF sources}

Table 3 specifies the above described sources of strong SMF in terms of the conditions in which any SMF with a magnetic flux density of more than $3 \mathrm{mT}$ can create a ballistic hazard, taking into account the possibility, or the lack thereof, of switching off the generation of SMF.

Tabela 3. Charakterystyka zagrożeń balistycznych związanych z eksploatacją źródeł silnego pola magnetostatycznego Table 3. Specification of sources of strong static magnetic field and the ballistic hazards which they can generate

\begin{tabular}{|c|c|c|c|c|}
\hline Urządzenie / Device & $\begin{array}{c}\text { Źródło silnego pola } \\
\text { magnetostatycznego / } \\
\text { Source of strong static } \\
\text { magnetic field }\end{array}$ & $\begin{array}{c}\text { Możliwość rutynowej } \\
\text { dezaktywacji źródła pola } \\
\text { magnetostatycznego / } \\
\text { Routine SMF source } \\
\text { deactivation possible }\end{array}$ & $\begin{array}{l}\text { Konieczność stosowania } \\
\text { specjalnych procedur } \\
\text { dezaktywacji źródła pola } \\
\text { magnetostatycznego / } \\
\text { The necessity of employing } \\
\text { special procedures of SMF } \\
\text { source deactivation }\end{array}$ & $\begin{array}{c}\text { Zasięg pola } \\
\text { magnetostatycznego, } \\
\text { w którym mogą wystąpić } \\
\text { zagrożenia balistyczne / } \\
\text { The range of static magnetic } \\
\text { field in which ballistic } \\
\text { hazards may occur }\end{array}$ \\
\hline \multirow{2}{*}{$\begin{array}{l}\text { skaner rezonansu } \\
\text { magnetycznego / } \\
\text { magnetic resonance } \\
\text { imaging scanner }\end{array}$} & $\begin{array}{l}\text { elektromagnes } \\
\text { nadprzewodzący / } \\
\text { superconducting } \\
\text { electromagnet }\end{array}$ & $\begin{array}{c}\text { brak } \\
\text { (dezaktywacja tylko } \\
\text { w sytuacjach } \\
\text { nadzwyczajnych) / } \\
\text { unavailable } \\
\text { (deactivation possible } \\
\text { in extraordinary } \\
\text { circumstances only) }\end{array}$ & tak / yes & ok. 2-3 m / approx. 2-3 m \\
\hline & $\begin{array}{l}\text { magnes trwały / } \\
\text { permanent magnet }\end{array}$ & brak / unavailable & $\begin{array}{c}\text { brak } \\
\text { (magnes trwały dezaktywuje } \\
\text { jedynie jego uszkodzenie } \\
\text { termiczne) / } \\
\text { unavailable } \\
\text { (permanent magnets can } \\
\text { be deactivated only when } \\
\text { damaged by temperature) }\end{array}$ & ok. $1 \mathrm{~m} /$ approx. $1 \mathrm{~m}$ \\
\hline $\begin{array}{l}\text { spektrometr rezonansu } \\
\text { magnetycznego / } \\
\text { magnetic resonance } \\
\text { spectrometer }\end{array}$ & $\begin{array}{l}\text { elektromagnes } \\
\text { nadprzewodzący / } \\
\text { superconducting } \\
\text { electromagnet }\end{array}$ & $\begin{array}{c}\text { brak } \\
\text { (dezaktywacja tylko } \\
\text { w sytuacjach } \\
\text { nadzwyczajnych) / } \\
\text { unavailable } \\
\text { (deactivation possible } \\
\text { only in extraordinary } \\
\text { circumstances) }\end{array}$ & tak / yes & ok. 0,5 m / approx. $0.5 \mathrm{~m}$ \\
\hline $\begin{array}{l}\text { chwytak } \\
\text { magnetyczny / } \\
\text { magnetic gripper }\end{array}$ & $\begin{array}{l}\text { elektromagnes rdzeniowy / } \\
\text { core electromagnet }\end{array}$ & tak / yes & nie / no & ok. $1 \mathrm{~m} /$ approx. $1 \mathrm{~m}$ \\
\hline $\begin{array}{c}\text { separator } \\
\text { magnetyczny / } \\
\text { magnetic separator }\end{array}$ & $\begin{array}{l}\text { elektromagnes rdzeniowy / } \\
\text { core electromagnet }\end{array}$ & tak / yes & nie / no & ok. $1 \mathrm{~m} /$ approx. $1 \mathrm{~m}$ \\
\hline
\end{tabular}

Źródło: Opracowanie własne.

Source: Own elaboration.

Scenariusze przykładowych zdarzeń wypadkowych związanych ze zjawiskiem balistycznym

Zagrażające życiu i zdrowiu strażaków skutki zjawiska balistycznego mogą wystąpić podczas działań operacyjnych lub ćwiczeń ewakuacyjnych w obiektach, w których zlokalizowane są omówione źródła silnego PMS.

Konieczność przeprowadzania ćwiczeń ewakuacyjnych w Polsce wynika z wytycznych określonych w rozporządzeniu Ministra Spraw Wewnętrznych i Administracji z dnia 7 czerwca 2010 r. w sprawie ochrony przeciwpożarowej budynków, innych obiektów budowlanych i terenów [11]. Konieczność przeprowadzenia praktycznego sprawdzenia organizacji i warunków ewakuacji co najmniej raz na 2 lata dotyczy placówek zatrudniających co najmniej 50 osób. W analizowanym zakresie taka konieczność obejmuje przede wszystkim szpitale, duże obiekty
Scenarios of possible accidents involving ballistic events

Health- and life-threatening effects of ballistic events can occur for firefighters during operations and fire drills conducted in structures containing the said sources of strong SMF.

Fire drills are a mandatory requirement in Poland under the guidelines set out in the Regulation of the Minister of the Interior and Administration of 7 June 2010 on the fire protection of buildings and other structures and areas [11]. Evacuations must be practised at least once every two years by any establishment with a workforce of at least 50 . As far as ballistic events are concerned, this is a requirement primarily for hospitals, large industrial facilities, specialised laboratory centres, major medical centres and specialised clinics. These measures aim to prepare the building and the employees working in it for actual health- or life-threatening situations, so 
przemysłowe, specjalistyczne ośrodki laboratoryjne, większe placówki medyczne i specjalistyczne przychodnie. Działania te mają na celu ocenę przygotowania obiektu i znajdujących się w nim pracowników do sytuacji rzeczywistego zagrożenia, dlatego działania takie należy przeprowadzać podczas normalnego funkcjonowania obiektu. Ze względu na liczne trudności w organizacji, specyfikę miejsc oraz możliwość spowodowania przypadkowego zagrożenia dla zdrowia i życia pacjentów, ćwiczenia takie bywają przeprowadzane rzadziej niż jest to określone $w$ rozporządzeniu. W tego typu placówkach należy liczyć się z występowaniem omawianych źródeł PMS.

Specyficzną formę zagrożeń stanowią wspomniane mobilne skanery rezonansu magnetycznego. Zagrożenie zjawiskiem balistycznym może wystąpić w tym przypadku w trakcie prowadzenia działań ratowniczo-technicznych na drogach publicznych $\mathrm{np}$. w sytuacji wypadku komunikacyjnego $\mathrm{z}$ udziałem ciągnika siodłowego przewożącego urządzenie $\mathrm{w}$ naczepie, ponieważ jak wspominano elektromagnes nadprzewodzący znajdujący się w urządzeniu jest aktywny podczas transportu. Jego dezaktywacja może nastąpić wskutek uszkodzenia lub wyłączenia instalacji chłodzącej elektromagnes ciekłym helem lub całkowitego wyczerpania energii z agregatu, który podtrzymuje zasilanie instalacji chłodzącej. Dochodzi wtedy do podwyższenia się temperatury uzwojenia elektromagnesu (zaniku zjawiska nadprzewodnictwa). Ponadto do dezaktywacji może dojść także w razie uszkodzenia lub uruchomienia procedury natychmiastowej dezaktywacji elektromagnesu skanera podczas wypadku.

\section{Dyskusja}

W wyniku działań operacyjnych wynikających z przytoczonego rozporządzenia [11] prowadzonych przez strażaków na terenie obiektu, gdzie znajduje się źródło silnego PMS, może dojść do zagrożenia bezpieczeństwa i zdrowia wskutek podatności wyposażenia strażaków na oddziaływanie PMS, gdy znajdą się oni w bliskim sąsiedztwie takiego źródła (tabela 3). Przedstawiony problem zagrożeń balistycznych nie dotyczy separatorów oraz chwytaków magnetycznych, ponieważ są one wyposażone w wyłączniki umożliwiające odłączenie zasilania, gdy nie są one eksploatowane. Natychmiast po wyłączeniu ich zasilania elektrycznego następuje dezaktywacja elektromagnesów rdzeniowych.

Istotność zagrożeń balistycznych występujących przy skanerach i spektrometrach rezonansu magnetycznego wynika $z$ faktu, że zagrożenia związane $z$ oddziaływaniem PMS mają charakter ciągły i występują, nawet gdy badania nie są prowadzone. Urządzenia te wyposażone są w wyłączniki umożliwiające awaryjną dezaktywację PMS poprzez rozwarcie obwodu elektromagnesu nadprzewodzącego, generującego silne PMS (rycina 3). Jednak wysokie koszty związane $z$ ich każdorazowym uruchomieniem sprawiają, że nie są one dezaktywowane poza szczególnymi sytuacjami awaryjnymi np. na czas prowadzonych ćwiczeń.

Dla strażaków możliwość wystąpienia zagrożeń balistycznych w przypadku spektrometrów rezonansu magnetycznego jest mniejsza niż przy skanerach rezonansu magnetycznego. Spektometry charakteryzują się zdecydowanie mniejszą rozległością silnego PMS mogącego oddziaływać na ferromagne- they should be conducted at times when the building functions normally. Due to a multitude of organisational difficulties, the unique qualities of each place wherein the specified drills are to be conducted, and the potential hazards to the health or life of patients of their undertaking, such drills do not take place in these establishments as often as prescribed by the Regulation, despite such establishments being highly likely to contain SMF sources.

The previously mentioned mobile magnetic resonance imaging scanners are a specific form of hazard. In this case, a ballistic-event hazard can occur during rescue operations on public roads - for instance, if there is an accident involving a trucktractor carrying the device in its semitrailer. This is because the superconducting electromagnet inside it is active while the vehicle is on its way. The fluid-helium cooling system of the magnet would have to be damaged or switched off, or the power generating unit which keeps the system going would have to run out of power, in order for the electromagnets to be deactivated as a result of an increase in the temperature of the electromagnet's winding (loss of super conduction). The electromagnets can also be deactivated during an accident when damaged, or when a procedure for its immediate deactivation is initiated

\section{Discussion}

The drills required under the Regulation [11] and conducted by firefighters in sites which contain sources of strong SMF may pose a hazard to life or health, since firefighter equipment becomes susceptible to SMF if close enough to it (Table 3). Ballistic hazard is not an issue for magnetic separators and grippers, though, as they have switches to turn the power off when not used. With no power supply, their core electromagnets are deactivated.

The major ballistic hazards associated with magnetic resonance imaging scanners and spectrometers are attributable to the continuous presence of SMF, even when the device is not on. They are equipped with switches designed to deactivate SMF by opening the circuit of the superconducting electromagnet which generates strong SMF (Figure 3), but it is highly expensive to activate them again, so this procedure is reserved for special or emergency situations and avoided during e.g. drills.

In terms of ballistic hazards, magnetic resonance spectrometers are less hazardous for firefighters than magnetic resonance imaging scanners. Indeed, the strong SMF generated by spectrometers has a much smaller range compared to that generated by magnetic resonance imaging scanners, and thus a much lower potential to affect the ferromagnetic pieces of firefighter equipment. Compare:

- a range of approx. $0.5 \mathrm{~m}$ from the casing of the device for a spectrometer's electromagnet

- a range of up to 2-3 $\mathrm{m}$ from the casing of the device for a scanner's electromagnet. 


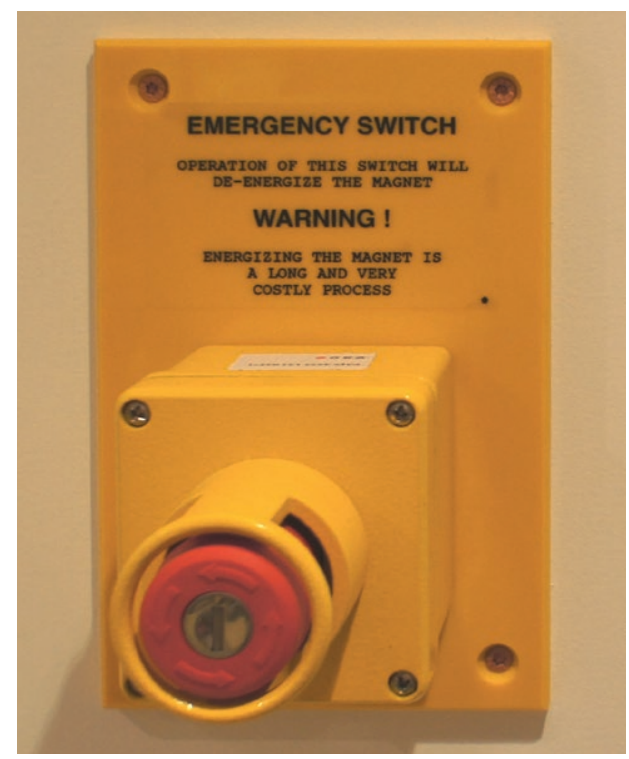

Rycina 3. Przykładowy awaryjny wyłącznik umożliwiający natychmiastową dezaktywację silnego PMS w skanerze rezonansu magnetycznego Figure 3. Example of an emergency switch to immediately deactivate the strong static magnetic field of a magnetic resonance imaging scanner Źródło: Opracowanie własne.

Source: Own elaboration.

tyczne elementy wyposażenia strażackiego w przeciwieństwie do skanerów rezonansu magnetycznego:

- ok. 0,5 m od obudowy elektromagnesu spektrometru,

- do 2-3 m od obudowy elektromagnesu skanera.

Jak wynika ze statystyk PSP w roku 2013 zarejestrowano 90 przypadków wystąpienia różnej wielkości pożarów w placówkach szpitalnych [8]. W budynku, w którym wystąpił pożar, podjęcie działań ratowniczo-gaśniczych powinno być rozpoczęte dopiero po odcięciu prądu za pomocą przeciwpożarowego wyłącznika prądu. Zgodnie z wymaganiami zawartymi w rozporządzeniu Ministra Infrastruktury w sprawie warunków technicznych, jakim powinny odpowiadać budynki i ich usytuowanie, odcięcie dopływu prądu z zastosowaniem tego wyłącznika powinno spowodować wyłączenie dopływu prądu do wszystkich obwodów wewnątrz danego budynku, oraz nie powinno spowodować samoczynnego załączenia drugiego źródła energii elektrycznej, w tym zespołu prądotwórczego [12]. Wyjątek stanowią źródła zasilające urządzenia elektryczne podtrzymujące życie, które muszą funkcjonować podczas pożaru. Do takich wyjątków zaliczyć można np. szpitalny blok operacyjny lub urządzenia na oddziale intensywnej terapii.

Natomiast w przypadku skanerów rezonansu magnetycznego, rozwiązaniem zalecanym przez producentów jest doprowadzenie zasilania z niezależnego źródła energii oraz zapewnienie instalacji zasilania awaryjnego (podtrzymującego). Ma to zapobiec nagłemu zanikowi energii zasilającej ciekłym helem instalację chłodzącą elektromagnes nadprzewodzący. W związku $z$ tym należy brać pod uwagę, że PMS skanera może być nadal aktywne, pomimo użycia wyłącznika przeciwpożarowego. Ponadto zanik zasilania elektrycznego nie dezaktywuje elektromagnesu nadprzewodzącego, w którym prąd elektryczny przepływa autonomicznie dopóki występują warunki nadprzewodnictwa. Placówki diagnostyczne przy szpitalach eksploatujące skanery
According to Polish State Fire Service statistics, a total of 90 fire incidents of varying sizes were recorded for medical centres in 2013 [8]. It is important to note that no rescue and extinguishing operations should start in a building before it is cut off from power using a fire switch. In line with the requirements of the Minister of the Interior Regulation pertaining to the technical conditions to be complied with by buildings and their locations, a fire switch should cut off power supply to all the circuits inside a building without automatically activating other power sources, including power generators [12]. As an exception, this does not apply to power sources for electric life support devices, which must be operational during a fire - for instance, for operating theatres or ICU (Intensive Care Unit) equipment.

As far as magnetic resonance imaging scanners are concerned, manufacturers recommend providing them with independent power supply and installing uninterrupted power supply units. This is to prevent sudden outages of the power needed to supply liquid helium to the cooling system of the superconducting electromagnet. Hence, firefighters should reckon with the possibility that the scanner's SMF is still active even though the fire switch has been used. What is more, the power outage will not deactivate the superconducting electromagnet, as the electric current will flow thought it independently as long as there is super conduction. Also of note, hospital diagnostic centres which operate magnetic resonance imaging scanners are sometimes independent entities with their own utilities.

If there is a traffic accident, the head of rescue operations (HRO) will make a reconnaissance to assess the situation. This is very important, as firefighters may come into direct contact with the mobile scanner if the reconnaissance has not been done properly or if the firefighters find themselves too close to the scanner - for instance when they are spreading, lifting 
rezonansu magnetycznego bywają samodzielnymi ośrodkami z wydzieloną infrastrukturą techniczną.

W razie wypadku komunikacyjnego, kierujący działaniami ratowniczymi (KDR) przeprowadza rozpoznanie i ocenia zaistniałą sytuację. Do bezpośredniego kontaktu strażaków z transportowanym mobilnym skanerem może dojść w wyniku błędnego rozpoznania lub przebywania $w$ jego bliskim otoczeniu np. podczas czynności operacyjnych takich jak rozszczepianie, podnoszenie i stabilizowanie samochodów, które uległy wypadkowi. W tych działaniach niezbędne jest zastosowanie narzędzi ratowniczych, które są dużo cięższe od ekwipunku osobistego i podręcznego użytkowanego przez strażaków podczas prowadzonych działań ratowniczych. Dodatkowo należy zwrócić uwagę, że podstawowy sprzęt ratownictwa technicznego (np. rozpieracze lub nożyce) często zasilany jest $z$ agregatu hydraulicznego. Elementy te są ze sobą połączone za pomocą węży hydraulicznych. W związku z powyższym w razie wystąpienia zjawiska balistycznego źródłem zagrożenia staje się nie tylko samo urządzenie, ale również przewody oraz agregat, które w wyniku pociągnięcia mogą stanowić zagrożenie dla prowadzących działania ratowników.

\section{BHP w czasie służby strażaków}

Strażacy muszą liczyć się z zagrożeniem życia i zdrowia podczas akcji ratowniczo-gaśniczych lub ćwiczeń. Rozporządzenie Ministra Spraw Wewnętrznych i Administracji z dnia 16 września 2008 r. w sprawie szczegółowych warunków bezpieczeństwa i higieny służby strażaków Państwowej Straży Pożarnej określa wytyczne dotyczące bezpieczeństwa strażaków PSP w takich sytuacjach oraz wymagania bezpieczeństwa i higieny służby w obiektach i pomieszczeniach przeznaczonych na użytek jednostek ratowniczo-gaśniczych, wymagania dotyczące wyposażenia strażaków w środki ochrony indywidualnej oraz zabezpieczenia medycznego podczas działań ratowniczo-gaśniczych, ćwiczeń i szkolenia [13].

Rozporządzenie to nie przewiduje specjalnych regulacji prawnych na wypadek konieczności prowadzenia przez strażaków działań ratowniczo-gaśniczych w narażeniu na silne PMS. Wymagania BHP w tym zakresie określają rozporządzenia Ministra Rodziny Pracy i Polityki Społecznej $[14,15]$.

Przeprowadzone rozpoznanie wykazało podatność niektórych elementów indywidualnego wyposażenia strażaków oraz sprzętu ratowniczego na oddziaływanie PMS. Analiza potencjalnych scenariuszy działania straży pożarnej wykazała możliwość zaistnienia sytuacji wymagającej podjęcia działań ratowniczogaśniczych, kontrolno-rozpoznawczych lub ćwiczeń, podczas których strażacy mogą być narażeni na silne PMS oraz możliwość wystąpienia zagrożeń balistycznych związanych z użytkowaniem wyposażenia indywidualnego oraz sprzętu ratowniczego przy źródłach PMS. W związku z powyższym zasadne jest przeprowadzenie rozpoznania oraz odrębnej szczegółowej analizy ze względu na podatność na PMS wyposażenia i sprzętu jednostek straży pożarnych.

Zgodnie z wymaganiami obowiązujących przepisów bezpieczeństwa i higieny pracy użytkownik źródła PMS powinien przy pracach związanych z narażeniem na pola elektromagnetyczne rozpoznać, ocenić i oznakować występujące zagrożenia elektro- and stabilising a car involved in an accident. These measures require rescue tools which are much heavier than the personal and carry-on gear used by firefighters during rescue operations. Also, it should be noted that the basic rescue equipment (e.g. spreaders or shears) is often powered by hydraulic power generators. Such equipment and generators are, therefore, interconnected through hydraulic hoses. By extension, if a ballistic event occurs, the hazard will come not only from the device alone, but also from the hoses and the power generator. Indeed, these might pose a danger to the firefighters when accidentally pulled or knocked.

\section{Firefighting $\mathrm{OSH}$}

Firefighters are facing an inherent hazard to their life and health during each rescue and extinguishing operation or drill. The Regulation of the Minister of the Interior and Administration of 16 September 2008 on the detailed health and safety conditions for the State Fire Service firefighters lays down the safety guidelines for such operations, and also the health and safety requirements applicable in the buildings and rooms used by rescue and firefighting units, as well as personal protection and medical protection requirements for rescue and extinguishing operations, drills and training [13].

The Regulation does not, however, contain any contingency provisions for operations involving firefighters' exposure to strong SMF. The OSH requirements in this respect are defined by the Ministry of Family, Labour and Social Policy Regulations $[14,15]$.

Our tests have shown that certain pieces of personal firefighter equipment and rescue equipment are susceptible to SMF. Furthermore, having analysed the potential scenarios of Fire Service operations, we have identified possible situations in which firefighters will have to engage in rescue and extinguishing, or reconnaissance, or drill operations involving their exposure to strong SMF, as well as possible ballistic hazards incidental to the use of personal or rescue equipment near SMF sources. There is all reason, therefore, to thoroughly investigate and test Fire Service equipment and gear for susceptibility to SMF.

Under applicable OSH laws, users of SMF-source devices whose work involves exposure to electromagnetic fields should identify, assess and provide signage of any existing electromagnetic hazards (including ballistic hazards), as well as mark SMF sources and ranges of protected zones (i.e. areas in which a ballistic event might occur), and the types of electromagnetic hazards that might occur there [14, 15]. Standardised signs may be used for this purpose, as in Figure 4 [16, 17, 18]. When placed in plain sight, this signs can prevent firefighters 
magnetyczne (także zagrożenia balistyczne) oraz oznakować źródła PMS i zasięgi stref ochronnych (tj. obszarów, w których może zaistnieć zjawisko balistyczne), a także rodzaje zagrożeń elektromagnetycznych, jakie mogą tam wystąpić $[14,15]$. Stosować do tego można znormalizowane znaki np. pokazane na ryc. $4[16,17$, 18]. Umieszczenie takich znaków w widocznych miejscach może zapobiec zagrożeniom wynikającym ze zbliżenia się strażaka (lub innej osoby) ze sprzętem o właściwościach ferromagnetycznych do aktywnego źródła silnego PMS. Ze względu na wspominane użytkowanie zarówno magnesów trwałych, jak i elektromagnesów nadprzewodzących, jako dobrą praktykę należy uznać traktowanie oznakowanych źródeł PMS jako zawsze aktywnych - dopóki nie zostanie potwierdzone ich dezaktywanie (wyłączenie pola). Szczególnej uwagi wymaga również niewłaściwa praktyka wielu użytkowników źródeł silnych PMS, polegająca na umieszczeniu znaków ostrzegających o zagrożeniach balistycznych w niewidocznych miejscach lub stosowanie znaków o zbyt małych rozmiarach, które można odczytać dopiero po zbliżeniu się do źródła PMS. (or other individuals) wearing or carrying highly ferromagnetic equipment from coming too close to an active source of strong SMF and thus creating an inherent hazard. As mentioned earlier, since both permanent magnets and superconducting electromagnets are in use, it should be a best practice to consider marked SMF sources as being always active until they are positively deactivated (that is, until the electromagnetic field is turned off). Special consideration should also be given to eliminating the inappropriate practice - common among users of devices generating strong SMF - of putting ballistic-hazard warning signs in inconspicuous places, or using signs which are too small and not legible unless the SMF source is approached.

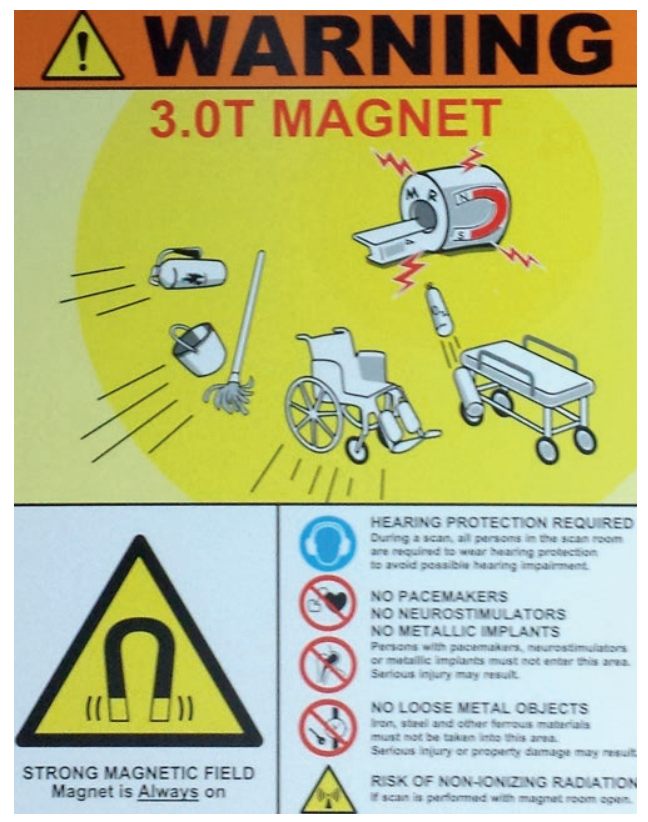

Rycina 4. Przykładowe znaki informujące o możliwości wystąpienia zagrożenia balistycznego

Figure 4. An example of a ballistic-hazard warning sign

Źródło: Opracowanie własne.

Source: Own elaboration.

\section{Podsumowanie}

Zagrożenia balistyczne mogą wystąpić w otoczeniu źródeł silnych PMS, szczególnie takich jak skanery i spektrometry rezonansu magnetycznego, chwytaki lub separatory magnetyczne, powodując np. uszkodzenia sprzętu, uszkodzenie ciała, a nawet utratę życia. Do grup zawodowych narażonych na tego typu niebezpieczeństwa należą również funkcjonariusze straży pożarnej prowadzący działania operacyjne w bliskim otoczeniu skanerów i spektrometrów rezonansu magnetycznego (np. w placówkach medycznych i naukowych). Z uwagi na specjalne i kosztowne procedury dezaktywacji i aktywacji takich źródeł silnego PMS są one zwykle stale aktywne.

\section{Summary}

Strong SMF sources, such as, in particular, magnetic resonance imaging scanners and spectrometers, magnetic grippers and separators, might pose ballistic hazards within their surroundings. These hazards, in turn, can cause damage to the equipment, bodily injuries, or even death. Such hazards are faced, among other occupations, by Fire Service officers working in the proximity of magnetic resonance imaging scanners and spectrometers (e.g. in medical centres or research institutes). The strong SMFs of these devices are usually active permanently, since the procedures for their deactivation are too complex and costly. 
Problematyka zagrożeń elektromagnetycznych powinna być omawiana podczas szkoleń oraz ćwiczeń strażaków. Powinny one uwzględniać rodzaje zagrożeń i rozpoznane okoliczności, w których mogą one wystąpić, sposoby ich oznakowania i ograniczania, tak aby możliwe było trenowanie procedur działania podczas akcji ratowniczych, również w specyficznych warunkach w pobliżu aktywnych źródeł silnych PMS.

Podczas czynności kontrolnych stanu zabezpieczenia przeciwpożarowego i warunków ewakuacji w placówkach, gdzie eksploatowane są źródła silnego PMS, należy również zwrócić szczególną uwagę na właściwe oznakowanie źródeł i dostateczną widoczność informacji o występujących tam zagrożeniach elektromagnetycznych. Powinny być także dostępne istotne dla strażaków informacje na temat sposobu awaryjnej dezaktywacji źródła tzn. sposobu natychmiastowego wyłączenia silnego PMS oraz eliminacji zagrożeń balistycznych w razie konieczności przebywania strażaków w pobliżu takiego źródła PMS.

Publikacja opracowana na podstawie wyników III etapu pragramu wieloletniego „Poprawa bezpieczeństwa i warunków pracy”, finansowanego w latach 2014-2016 w zakresie zadań służb państwowych przez Ministertwo Rodziny, Pracy i Polityki Społecznej (zadanie 2.Z.30). Koordynator programu: Centralny Instytut Ochrony Pracy - Państwowy Instytut Badawczy

\section{Wykaz skrótów}

BHP - bezpieczeństwo i higiena pracy

PMS - pole magnetostatyczne

PSP - Państwowa Straż Pożarna

\section{Literatura / Literature}

[1] Karpowicz J., Gryz K., Politański P., Zmyślony M., Narażenie na pole magnetostatyczne i zagrożenia zdrowia przy obsłudze skanerów rezonansu magnetycznego, "Med. Pr." 2011, 62(3), 309-321.

[2] Karpowicz J., Gryz K., Ocena zagrożeń balistycznych w placówkach diagnostyki obrazowej na podstawie badań eksperymentalnych, „Pol. J. Radiol." 2013; 78(2), DOI: 10.12659/PJR.883943.

[3] Portal internetowy „BEZPIECZNIEJ", http://www.ciop.pl/bezpieczniej [dostęp: 10.09.2016].

[4] Resnick R., Halliday D., Walker J., Fundamentals of Physics, 9th edition, 2012

[5] Chen D.W., Boy, 6, dies of skull injury during M.R.I., "NY Times" 2001; Jul 31:Sec. B:1,5 [electr. doc.] http://ducknetweb.blogspot.com/2010/06/ mri-accident-earlier-this-year-kills.html [accessed: 30.06.2016].

[6] Materiały dydaktyczne prezentowane podczas kursu podstawowego dla Ochotniczych Straży Pożarnych "Szkolenie strażaków-ratowników OSP cz. 1", KM PSP w Warszawie, 9.05-13.06.2015.

[7] Rozporządzenie Ministra Spraw Wewnętrznych i Administracji z dnia 30 listopada 2005 r. w sprawie umundurowania strażaków Państwowej Straży Pożarnej (Dz.U. z 2006 r. Nr 4, poz. 25).

[8] Biuletyn Informacyjny Państwowej Straży Pożarnej za rok 2013, KG PSP, Warszawa 2014.

[9] Sikora R., Teoria pola elektromagnetycznego, Wydawnictwa Naukowo-Techniczne, wydanie 3, 1997.
Hence, electromagnetic hazards should be discussed during firefighters' training and exercises. This should include the types of these hazards and the known circumstances in which they might occur, as well as the means whereby they can be marked and contained, so as to enable the Fire Service to practice rescue operational procedures, including in the proximity of strong SMF sources.

Fire-safety and evacuation-safety inspections conducted in buildings where devices generating strong SMF are operated should pay special attention to whether or not these SMF sources are properly marked, and also to whether the electromagneticwarning signs are sufficiently legible. It would also be advisable for such buildings to have instructions in place for firefighters on how to proceed with the emergency deactivation of SMF sources, that is, how to immediately switch off any strong SMF source and eliminate ballistic hazards should the firefighters have to approach such an SMF source.

This paper has been based on the results of research carried out within the scope of the third of the National Programme "Improvement of safety and working conditions" partly supported in 2014-2016 within the scope of state services by Ministry of Family, Labour and social Policy (task 2.Z.30). The main coordinator of the Programme: The Central Institute for Labour Protection - National Research Institute

\section{List of abbreviations}

OSH - occupational health \& safety

SMF - static magnetic field

SFS - State Fire Service

[10] Karpowicz J. (red.), Zagrożenia w placówkach diagnostyki obrazowej - wymagania bezpieczeństwa i higieny pracy oraz zasady profilaktyki, CIOP-PIB, Warszawa 2015, 50.

[11] Rozporządzenie Ministra Spraw Wewnętrznych i Administracji z dnia 7 czerwca 2010 r. w sprawie ochrony przeciwpożarowej budynków, innych obiektów budowlanych i terenów (Dz.U. Nr 109, poz. 719).

[12] Rozporządzenie Ministra Infrastruktury z dnia 12 kwietnia 2002 r. w sprawie warunków technicznych, jakim powinny odpowiadać budynki i ich usytuowanie (Dz.U. Nr 75, poz. 690).

[13] Rozporządzenie Ministra Spraw Wewnętrznych i Administracji z dnia 16 września 2008 r. w sprawie szczegółowych warunków bezpieczeństwa i higieny służby strażaków Państwowej Straży Pożarnej (Dz.U. Nr 180, poz. 1115).

[14] Rozporządzenie Ministra Rodziny Pracy i Polityki Społecznej z dnia 29.06.2016 r. w sprawie bezpieczeństwa i higieny pracy przy pracach związanych z narażeniem na pola elektromagnetyczne (Dz.U. poz. 950).

[15] Rozporządzenie Ministra Rodziny, Pracy i Polityki Społecznej z dnia 27.06.2016 r. zmieniające rozporządzanie w sprawie najwyższych dopuszczalnych stężeń i natężeń czynników szkodliwych dla zdrowia w środowisku pracy (Dz.U. poz. 952).

[16] PN-93/N-01256/03 Znaki bezpieczeństwa. Ochrona i higiena pracy.

[17] PN-74/T-06260 Źródła promieniowania elektromagnetycznego. Znaki ostrzegawcze.

[18] PN-ISO 7010:2012 Symbole graficzne. Barwy bezpieczeństwa i znaki bezpieczeństwa. Zarejestrowane znaki bezpieczeństwa. 
MGR INŻ. WIESŁAW LESZKO - ukończył szkołę Główną Służby Pożarniczej w 2007 roku. Obecnie jest zatrudniony w Pracowni Zagrożeń Elektromagnetycznych w Centralnym Instytucie Ochrony Pracy - Państwowym Instytucie Badawczym.

DR INŻ. KRZYSZTOF GRYZ - w 2004 obronił doktorat w Centralnym Instytucie Ochrony Pracy - Państwowym Instytucie Badawczym. Obecnie jest zatrudniony jako adiunkt w Pracowni Zagrożeń Elektromagnetycznych tego Instytutu.
WIESŁAW LESZKO, M.Sc.Eng. - graduated from The Main School of Fire Service in 2007. He is currently employed at the Electromagnetic Hazards Laboratory, the Central Institute for Labour Protection - National Research Institute.

KRZYSZTOF GRYZ, Ph.D. Eng. - obtained a Ph.D. degree from the Central Institute for Labour Protection - National Research Institute in 2004. He is currently Assistant Professor at the Laboratory of Electromagnetic Hazards, the Central Institute for Labour Protection - National Research Institute. 